Journal Knowledge Industrial Engineering (JKIE)

\title{
ANALISIS STRATEGI PEMASARAN DENGAN MENGGUNAKAN METODE SWOT DAN QSPM PADA PT. SENTRAL PERKASA JAYA
}

\author{
(1)Rizky Wahyudi, (2)Purnomo \\ (1)(2) Prodi Teknik Industri - Fakultas Teknik - Universitas Machung \\ Email Koresponden : 411410015@student.machung.acid
}

\begin{abstract}
Abstraks
PT.Sentral Perkasa Jaya adalah sebuah perusahaan yang bergerak di bidang transportasi yaitu ekspedisi.Masalah yang dihadapi adalah perkembangan teknologi yang menyebabkan persaingan bisnis yang ketat, sehingga menyebabkan penurunan tingkat pendapatan dari tahun ke tahun.Selain itu, strategi yang digunakan juga cenderung monoton sehingga menyebabkan perusahaan kalah bersaing dengan perusahaan lainnya. Dalam mengatasi permasalahan strategi pemasaran yang ada di perusahaan tersebut, maka akan dilakukan analisis mengenai faktor-faktor internal dan eksternal yang ada di perusahaan. Selanjutnya faktor-faktor internal dan eksternal yang ada di perusahaan akan dianalisis lagi menggunakan matriks SWOT dan matriks IE. Setelah itu akan digunakan analisis QSPM untuk mengambil keputusan mengenai pemilihan strategi yang tepat untuk diterapkan. Berdasarkan perumusan strategi yang telah dilakukan menggunakan dua metode yaitu SWOT dan IE, maka strategi alternative yang tepat untuk perusahaan adalah strategi penetrasi pasar dan strategi pengembangan produk. Hasil dari metode QSPM menunjukkan bahwa alternative strategi yang terbaik adalah strategi pengembangan produk dengan total skor sebesar 5,47. Strategi pengembangan produk ini adalah strategi dimana perusahaan melakukan perbaikan produk yang sudah ada atau mengembangkan produk yang baru sehingga dapat meningkatkan penjualan.
\end{abstract}

Kata Kunci: Strength Weakness Opportunities Threat Matrix (SWOT), Internal-External Matrix (IE), Quantitative Strategic Planning Matrix (QSPM).

\begin{abstract}
PT. Sentral Perkasa Jaya is a company that's move in expedition. The problem faced is the development of technology causing intense business competition, resulting in decreased level of corporate income from year to year. In addition, the strategies used also tend to be monotonous, causing companies to compete with other companies. There are many problem of marketing strategy in the company, it can be an analysis of internal and external factors in the company. Next, internal and external factors will be analyzed again using SWOT matrix and IE matrix. After that Quantitative Strategic Planning Matrix (QSPM) are used to analyze decision making selection about appropriate strategies applied $n$ the company. Based on the calculation of strategies that have been done using two methods, SWOT and IE, then the appropriate alternative strategy for the company is a market penetration strategy and product development strategy. The results of the QSPM method indicate that the best alternative strategy is the product development strategy with a total score of 5.47. This product development strategy is a strategy whereby a company does an existing product repair, or develops a new product to increase sales.

.Keywords :Strength Weakness Opportunities Threat Matrix (SWOT), Internal-External Matrix (IE), Quantitative Strategic Planning Matrix (QSPM).
\end{abstract}

\section{PENDAHULUAN}

Kota Surabaya yang berkembang begitu pesat telah menjadi kawasan strategis untuk memulai usaha dan bisnis.Salah satu usaha yang menjanjikan adalah melakukan jual-beli, 
pertukaran barang dan melakukan hubungan sosial yaitu dengan mengirim suatu barang oleh individu, perusahaan, atau kelompok sosial. Salah satunya adalah PT. Sentral Perkasa Jaya yang bergerak dibidang jasa pengiriman barang, yang berusaha mencari peluang bisnis dengan memberikan fasilitas yang memadai untuk kegiatan jasa pengiriman barang seperti hasil pertanian, sembako, bahan baku material, minyak, kendaraan bermotor, dan barang elektronik. Penentuan harga barang yang dipakai adalah dengan menggunakan sistem perkilo, perkoli, dan perunit.

PT. Sentral Perkasa Jaya juga dikenal sebagai perusahaan yang sudah lama bergerak di bidang jasa pengiriman barang.Dampak persaingan yang semakin ketat dengan perusahaan ekspedisi lainnya seperti PT. Sumber Manis dan PT. Hasil Lasem Indah mengakibatkan penurunan tingkat pendapatan perusahaan dari tahun ke tahun.

Penurunan keuntungan yang diperoleh perusahaan disebabkan oleh strategi pemasaran yang monoton, sehingga diperlukan perbaikan strategi pemasaran yang diterapkan oleh perusahaan.Perbaikan strategi pemasaran tersebut yang berkaitan dengan faktor-faktor yang berasal dari lingkungan internal dan eksternal perusahaan, serta posisi perusahaan terhadap pangsa pasar dan tingkat pertumbuhan pengguna jasa pengiriman dari perusahaan.

Melalui penelitian ini, akan dilakukan analisis mengenai faktor-faktor internal dan eksternal dari kekuatan, kelemahan, ancaman, dan peluang. Analisis ini adalah analisis Strength Weakness Opportunities Threats Matrix (SWOT), dan analisis Quantitave Strategic Planning Matrix (QSPM) yang sangat penting dalam pengambilan keputusan mengenai pemilihan strategi pemasaran yang tepat untuk diterapkan di perusahaan.

\section{METODE PENELITIAN \\ Pemasaran Jasa}

Pemasaran jasa merupakan sebuah proses pemasaran yang tidak dapat diidentifikasi secara jelas gambaran produknya (Kotler dan Armstrong, 2009,p 469). Pemasaran di bidang jasa akan teridentifikasi apabila terdapat hubungan langsung (interpersonal) antara produsen dan konsumen. Hubungan antara konsumen dan produsen ini akan diukur melalui kepuasan kesepakatan. Terdapat berbagai elemen yang mempengaruhi proses pemasaran jasa, seperti system internal organisasi, lingkungan fisik, kontak personal, iklan, tagihan dan pembayaran, dan komentar dari mulut ke mulut. Pemasaran jasa juga dapat diartikan sebagai suatu proses mempersepsikan, memahami, menstimulasi dan memenuhi kebutuhan pasar yang dipilih secara khusus dan menyalurkan sumber-sumber sebuah organisasi untuk memenuhi kebutuhan (Hurriyati, 2010, p 42).

\section{Strategi Pemasaran}

Strategi pemasaran berasal dari bahasa Yunani yaitu strategi yang berarti seni atau ilmu untuk menjadi seorang jenderal (Tjiptono, 2008, p 43). Konsep strategi militer seringkali digunakan dan diterapkan dalam dunia bisnis yang mengikuti lingkungan yang dipilih dan merupakan pedoman untuk mengalokasikan sumber daya dan usaha suatu perusahaan.Sehingga strategi pemasaran adalah rencana yang hendak diikuti oleh manajer pemasaran. Rencana tindakan ini didasarkan atas analisis situasi dan tujuan-tujuan perusahaan dan merupakan cara untuk pencapaian tujuan tersebut.

Pengertian strategi merupakan proses perencanaan yang dimiliki oleh suatu perusahaan dan dilaksanakan secara terus-menerus (Kotler, 1998, p 57).

\section{Penilaian Faktor Eksternal}

Matriks faktor eksternal (Eksternal Factor Evaluation) adalah suatu matriks yang menampilkan faktor-faktor eksternal yang mempengaruhi organisasi atau perusahaan dalam menjalankan 
usahanya (David, 2009).Sebelum membuat faktor strategi eksternal, perlu diketahui faktor-faktor eksternal yang berkaitan dengan perusahaan.Antara lain faktor ekonomi, budaya, demografi, lingkungan, politik, pemerintahan, legalitas, teknologi, dan informasi persaingan. Berikut ini adalah cara-cara untuk membuat EFE Matrix (David, 2009):

1.Menyusun 10 sampai 20 buah, peluang dan ancaman dalam kolom pertama.

2. Memberi bobot masing-masing faktor dalam kolom 2, mulai dari 0,0 (tidak penting) sampai 1,0 (penting). Sedangkan jumlah keseluruhan bobot harus sama dengan 1,0. Faktor-faktor tersebut kemungkinan dapat memberikan dampak terhadap faktor strategis.

3. Menghitung rating (dalam kolom 3) untuk masing-masing faktor untuk memberikan skala mulai dari 1 (poor) hingga 4 (outstanding) berdasarkan pengaruh dari faktor tersebut terhadap perusahaan yang bersangkutan. Pemberian rating untuk faktor-faktor eksternal tersebut bersifat positif (peluang yang semakin besar diberi rating +4 , apabila peluang memiliki pengaruh biasa saja atau average maka diberi rating +3 , apabila pengaruhnya dibawah average maka diberi rating +2 , dan jika peluangnya kecil diberi rating +1 ).

4. Mengalikan bobot pada kolom 2 dengan rating pada kolom 3, untuk memperoleh faktor pembobotan pada kolom 4. Hasilnya adalah skor pembobotan untuk masing-masing faktor yang nilainya bervariasi mulai dari 1,0 (poor) sampai dengan 4,0 (outstanding).

5. Menjumlahkan skor pembobotan (pada kolom 4), untuk memperoleh total skor pembobotan untuk perusahaan yang bersangkutan. Nilai total ini menunjukkan bagaimana perusahaan tersebut bereaksi terhadap faktor-faktor strategis eksternalnya. Total skor ini dapat digunakan untuk membandingkan perusahaan ini dengan perusahaan lainnya dalam satu kelompok industri yang sama.

\section{Penilaian Faktor Internal}

Tahap ekstraksi dalam menjalankan audit internal manajemen strategi adalah dengan membuat Internal Factor Evaluation (IFE). Alat formulasi strategi ini adalah meringkas dan mengevaluasi kekuatan dan kelemahan utama dalam area fungsional bisnis, dan juga memberikan dasar untuk mengidentifikasi dan mengevaluasi hubungan antara area-area tersebut.Penilaian intuitif dibutuhkan dalam mengembangkan matriks IFE. Berikut merupakan tahapan-tahapan pembuatan matriks IFE (David, 2009):

1.Menyusun 10 sampai 20 buah, kekuatan dan kelemahan dalam kolom pertama.

2. Memberi bobot masing-masing faktor dalam kolom 2, mulai dari 0,0 (tidak penting) sampai 1,0 (penting). Sedangkan jumlah keseluruhan bobot harus sama dengan 1,0. Faktor-faktor tersebut kemungkinan dapat memberikan dampak terhadap faktor strategis.

3. Menghitung rating (dalam kolom 3) untuk masing-masing faktor untuk memberikan skala mulai dari 1 (poor) hingga 4 (outstanding) berdasarkan pengaruh dari faktor tersebut terhadap perusahaan yang bersangkutan. Pemberian rating untuk faktor-faktor eksternal tersebut bersifat positif (peluang yang semakin besar diberi rating +4 , apabila peluang memiliki pengaruh biasa saja atau average maka diberi rating +3 , apabila pengaruhnya dibawah average maka diberi rating +2 , dan jika peluangnya kecil diberi rating +1 ).

4. Mengalikan bobot pada kolom 2 dengan rating pada kolom 3, untuk memperoleh faktor pembobotan pada kolom 4. Hasilnya adalah skor pembobotan untuk masing-masing faktor yang nilainya bervariasi mulai dari 1,0 (poor) sampai dengan 4,0 (outstanding).

5. Menjumlahkan skor pembobotan (pada kolom 4), untuk memperoleh total skor pembobotan untuk perusahaan yang bersangkutan. Nilai total ini menunjukkan bagaimana perusahaan tersebut bereaksi terhadap faktor-faktor strategis internalnya. Total skor ini dapat digunakan untuk membandingkan perusahaan ini dengan perusahaan lainnya dalam satu kelompok industri yang sama. 


\section{Analisis Pembobotan AHP}

Hirarki didefinisikan sebagai suatu representasi dari sebuah permasalahan yang kompleks dalam suatu struktur multi level dimana level pertama adalah tujuan, yang diikuti level faktor, kriteria, sub kriteria, dan seterusnya ke bawah hingga level terakhir dari alternative (Saaty, 1993). Melalui meode ini, suatu masalah yang kompleks dapat diuraikan kedalam kelompok-kelompoknya yang kemudian diatur menjadi suatu bentuk hirarki sehingga permasalahan akan tampak lebih terstruktur dan sistematis. Analitical hierarchy process merupakan suatu model yang fleksibel yang memungkinkan peneliti mengambil keputusan dengan mengkombinasikan pertimbangan dan nilai pribadi secara logis.

AHP sendiri merupakan sistem pembuat keputusan dengan menggunakan model matematis, AHP juga membantu dalam menentukan prioritas dari beberapa kriteria dengan melakukan analisa perbandingan berpasangan dari masing-masing kriteria.Dalam sistem pengelolaan kinerja yang dimaksud dengan kriteria tersebut adalah KPI. Kaidah pembobotan menyatakan bahwa (Saaty, 1993):

1. Nilai bobot KPI berkisar antara 0-1.

2. Jumlah total bobot semua KPI harus bernilai 1.

3. Tidak ada bobot yang bernilai negative $(-)$.

\section{Analisis SWOT}

Konsep dasar pendekatan SWOT tampaknya sederhana, yaitu apabila kita dapat mengetahui kekuatan (strength) dan kelemahan (weakness) organisasi kita dan mengetahui peluang (opportunity) dari luar organisasi yang menguntungkan serta ancaman (threat) di dalam organisasi yang merugikan organisasi atau perusahaan kita. Tentang matriks SWOT menggunakan beberapa strategi, yaitu (Salusu, 2000, p 35):

1. Strategi S.O, yaitu memanfaatkan peluang yang ada dengan keunggulan organisasi (comparative advantage comparative).

2. Strategi S.T, yaitu memobilisasi beberapa keunggulan untuk mencapai sasaran (mobilization).

3. Strategi W.O, yaitu memilih faktor mana yang dipacu dan faktor mana yang ditunda (investmen atau divestmen).

4. Strategi W.T, yaitu perlu kehati-hatian atau kewaspadaan dalam mencapai sasaran (damage control).

Tujuan pemilikan strategi adalah untuk menjamin ketepatan pencapaian sasaran (Kurniawan, 2008, p 70).Suatu rancangan strategi dapat dipilih untuk menutup kesenjangan dalam mencapai sasaran.Sifat kesenjangan itu sendiri juga sangat situasional. Kalau kesenjangan akibat prestasi di masa lampau yang sangat buruk penciutan lebih mungkin dilakukan dan bila kesenjangan itu besar sebagai akibat dari peluang lingkungan yang diharapkan, maka akan lebih tepat bila dilakukan ekspansi.

Penelitian menunjukan bahwa kinerja perusahaan dapat ditentukan oleh kombinasi faktor eksternal dan internal. Kedua faktor tersebut harus dipertimbangkan dalam analisis SWOT. SWOT adalah singkatan dari lingkungan Internalyaitu Strengths dan Weakness serta lingkungan eksternal yaitu Opportunities dan Threats yang dihadapi dalam dunia bisnis. Analisis SWOT membandingkan antara faktor eksternal peluang (opportunities) dan ancaman (threats) dengan faktor internal kekuatan (strengths) dan kelemahan (weaaknesses).

Kuadran I : ini merupakan situasi yang sangat menguntungkan perusahaan. Perusahaan memiliki peluang dan kekuatan sehingga perusahaan dapat memanfaatkan peluang yang ada. Strategi yang 
harus diterapkan dalam kondisi ini adalah mendukung kebijakan pertumbuhan yang agresif (Growth oriented strategy).

Kuadran 2 : Meskipun menghadapi berbagai macam ancaman, perusahaan ini masih memiliki kekuatan dari segi internal. Strategi yang harus diterapkan adalah menggunakan kekuatan perusahaan untuk memanfaatkan peluang jangka panjang dengan cara strategi diversifikasi (produk atau jasa).

Kuadran 3 : Perusahaan menghadapi peluang pasar yang sangat besar, tetapi di lain pihak, ia menghadapi beberapa kendala atau kelemahan internal. Kondisi bisnis pada kuadarn 3 ini mirip dengan Question Mark pada BCG Matrix.Fokus strategi perusahaan ini adalah meminimalkan masalah-masalah internal perusahaan sehingga dapat merebut peluang pasar yang lebih. Misalnya, Apple menggunakan strategi peninjauan kembali teknologi yang dipergunakan dengan cara menawarkan produk-produk baru dalam industry microcomputer.

Kuadran 4 : Ini merupakan situasi yang sangat tidak menguntungkan, perusahaan tersebut menghadapi berbagai ancaman dan kelemahan internal.

\section{Quantitative Strategic Planning Matrix (QSPM)}

Setelah pemaparan matriks-matriks pada tahap masukan dan tahap analisis, maka tahapan berikutnya adalah tahapan pengambilan keputusan (decision stage) yang akan menyusun daftar prioritas strategi yang harus diimplementasikan. Quantitave Strategic Planning Matrix (QSPM) merupakan teknik yang secara obyektif dapat menetapkan strategi alternatif yang diprioritaskan.QSPM sendiri adalah alat yang memungkinkan para penyusun strategi mengevaluasi hasil berbagai strategi alternative secara obyektif berdasarkan faktor-faktor keberhasilan penting eksternal dan internal yang telah diidentifikasi sebelumnya (David, 2009).Sedangkan menurut Umar (2003) QSPM adalah menetapkan kemenarikkan relative dari strategi-strategi yang bervariasi yang dipilih, untuk menentukan strategi mana yang dianggap paling baik untuk diimplementasikan.

\section{HASIL DAN PEMBAHASAN}

Dalam pelaksanaannya, hasil dari penelitian ini fokus dalam pembuatan :

1.Analisis Lingkungan perusahaan

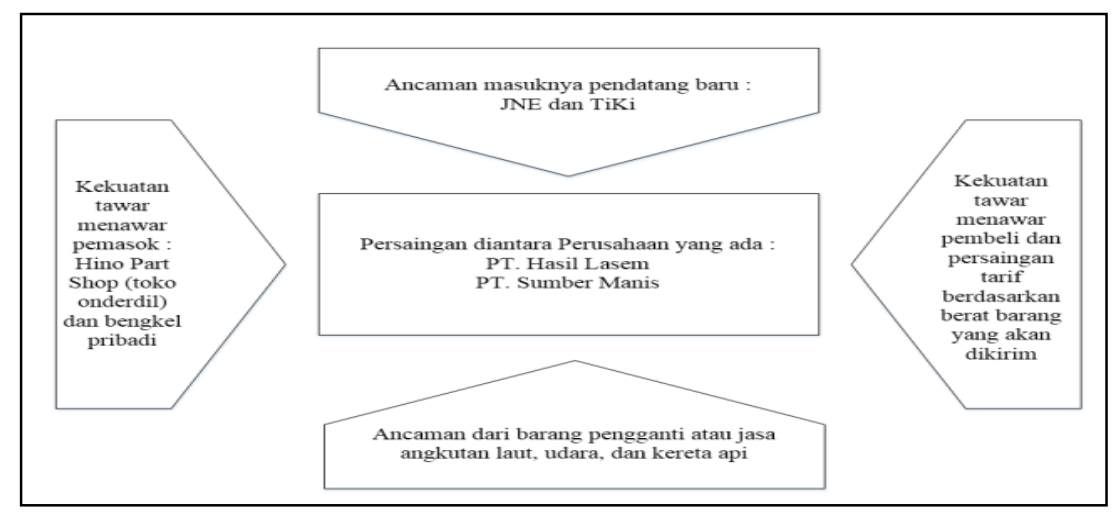

Gambar : 1. Model Lima Kekuatan Porter di Perusahaan

\section{Strategi bauran pemasaran (7P)}

Bauran Pemasaran juga diperlukan oleh PT. Sentral Perkasa Jaya dalam menjalankan bisnis. Berikut merupakan bauran pemasaran yang ada di PT. Sentral Perkasa Jaya:

1. Product (produk)

2. Price (harga) 


\section{Place (lokasi) \\ 4. People (orang) \\ 5. Promotion (promosi) \\ 6. Process (proses) \\ 7. Physical Evidence (bukti fisik)}

\section{Tahap Input}

Kekuatan dan kelemahan merupakan faktor internal perusahaan sedangkan peluang dan ancaman merupakan faktor eksternal perusahaan. Berikut merupakan faktor dari kekuatan (strength) perusahaan:

1. Jumlah armada yang banyak. Hal ini dapat dilihat dari profile perusahaan yang menyatakan bahwa PT. Sentral Perkasa Jaya memiliki jumlah armada sebanyak 40 kendaraan, yang terdiri dari 17 truk engkel, 8 truk wing box, 10 truk gandengan dan 5 kontainer.

2. Aset perusahaan yang besar berupa gudang dan tempat parkir truk yang ada di kota Surabaya dan Jakarta. Luas bangunan yang ada di Surabaya sebesar $10.800 \mathrm{~m}^{2}$ sedangkan yang ada di Jakarta sebesar $8.400 \mathrm{~m}^{2}$.

3. Pangsa pasar yang besar. Hal ini dapat dilihat berdasarkan hasil survey memperlihatkan bahwa pelanggan yang ada di PT. Sentral Perkasa Jaya lebih besar dibandingkan dengan para pesaingnya.

4. Jumlah rute yang banyak. Hal ini dapat dilihat berdasarkan wawancara dari supir yang ada. Rute yang dilewati oleh supir beragam-ragam sehingga terdapat sedikitnya sepuluh rute yang sering dilewati oleh supir. Mulai dari rute jalur pantura, rute laut selatan, hingga rute jalan yang lainnya.

Selain faktor-faktor dari kekuatan (strength) perusahaan, terdapat pula faktor-faktor kelemahannya (weaknesses). Berikut merupakan faktor dari kelemahan (weaknesses) perusahaan:

1. Jenis dan tipe truk yang ada di perusahaan merupakan tipe keluaran yang lama. Hal ini dapat diketahui dari surat-surat kendaraan tersebut yang rata-rata berumur 10-12 tahun.

2. Kurangnya promosi, promosi ini juga dapat membantu melancarkan pemasaran perusahaan serta dapat membangun hubungan yang baik dengan pelanggan. Hal tersebut berhubungan dengan tingkat keuntungan perusahaan yang berkurang tiap tahunnya.

3. Operasional belum maksimal. Hampir seluruh pekerjaan yang ada di perusahaan menggunakan cara yang manual. Mulai dari pencatatan pesanan, pencatatan gudang, hingga totalan supir juga menggunakan cara yang manual.

4. Kualifikasi SDM yang masih rendah. Hal ini dapat dilihat dari mayoritas karyawan perusahaan yang berpendidikan rendah yaitu rata-rata lulusan SD dan SMP, selain itu pendidikan dan pelatihan internal perusahaan masih kurang diaplikasikan secara maksimal.

Berikut merupakan faktor dari peluang (opportunities) perusahaan:

1. Tidak terikat oleh waktu. Sesuai dengan peraturan yang ada di perusahaan, armada akan berangkat jika armada tersebut sudah terisi penuh. Hal ini diterapkan perusahaan untuk memaksimalkan armada yang ada.

2. Keamanan yang terjaga. Selain mempunyai ijin resmi dari pemerintah, PT. Sentral Perkasa Jaya ini juga memiliki komunitas jalanan yang menjaga armada di sepanjang perjalanan. Selain itu, barang yang akan dikirim juga memiliki asuransi dari perusahaan.

3. Pangsa pasar yang besar. Hal ini terjadi karena PT. Sentral Perkasa Jaya ini memiliki nama yang terkenal dan termasuk perusahaan yang sudah lama berdiri. 
4. Lokasi yang strategis. Letak kantor PT. Sentral Perkasa Jaya terletak di pusat kota Surabaya dan pusat kota Jakarta. Sehingga letak kantornya mudah untuk dicari dan memiliki halaman yang luas untuk parkir.

Selain faktor-faktor dari kekuatan (strength) perusahaan, kelemahan (weaknesses), dan peluang (opportunities) terdapat pula faktor-faktor ancaman (threats). Berikut merupakan faktor dari ancaman (threats) perusahaan:

1. Banyaknya pesaing. Pertumbuhan ekspedisi angkutan darat mengalami kenaikan tiap tahunnya. Hal ini dapat dibuktikan dengan hasil wawancara yang membahas tentang semakin banyaknya perusahaan-perusahaan baru yang muncul di bidang yang sama.

2. Murahnya harga pesaing. Persaingan antar perusahaan yang semakin ketat salah satunya disebabkan oleh harga. Banyak perusahaan-perusahaaan baru yang memberikan diskon yang cukup besar. Informasi ini didapat dari wawancara dengan divisi pemasaran.

3. Munculnya kereta api. Berdasarkan hasil dari wawancara dengan divisi pemasaran, yang memiliki pangsa pasar terbesar ekspedisi saat ini adalah kereta api logistik. Selain memiliki harga yang murah, kereta api logistik juga memiliki waktu pengiriman yang cepat.

Mahalnya harga BBM. Bahan bakar minyak di Indonesia saat ini semakin lama harganya semakin meningkat. Berdasarkan hasil wawancara dengan supir yang ada di perusahaan sudah mengalami kenaikan sebanyak empat kali pada tahun 2017.

Berikut adalah hasil analisis menggunakan matriks IFE:

Tabel : 1. HasilInternal Factor Evaluation Matrix (IFE Matrix)

\begin{tabular}{|c|c|c|c|}
\hline Faktor Internal & $\begin{array}{c}\text { Nilai } \\
\text { Terbobot }\end{array}$ & $\begin{array}{c}\text { Nilai } \\
\text { Peringkat }\end{array}$ & $\begin{array}{l}\text { Total } \\
\text { Nilai }\end{array}$ \\
\hline \multicolumn{4}{|c|}{ Kekuatan } \\
\hline $\begin{array}{l}\text { Jumlah armada } \\
\text { yang banyak }\end{array}$ & 0.126 & 3.725 & 0.46935 \\
\hline $\begin{array}{l}\text { Banyaknya } \\
\text { aset perusahaan }\end{array}$ & 0.111 & 3.25 & 0.36075 \\
\hline $\begin{array}{l}\text { Pangsa pasar } \\
\text { yang besar }\end{array}$ & 0.114 & 2.55 & 0.2907 \\
\hline Banyak rute & 0.122 & 2.925 & 0.35685 \\
\hline \multicolumn{4}{|c|}{ Kelemahan } \\
\hline $\begin{array}{l}\text { Armada } \\
\text { berumur tua }\end{array}$ & 0.123 & 2.075 & 0.255225 \\
\hline $\begin{array}{l}\text { Kurangnya } \\
\text { promosi }\end{array}$ & 0.124 & 2.275 & 0.2821 \\
\hline $\begin{array}{l}\text { Operasional } \\
\text { belum maksimal }\end{array}$ & 0.134 & 2.1 & 0.2814 \\
\hline SDM rendah & 0.146 & 1.2 & 0.1752 \\
\hline Total & 1 & & 2.471575 \\
\hline
\end{tabular}

Berdasarkan tabel 4.5 hasil matriks IFE didapatkan total nilai terbobot sebesar 2,47. Berdasarkan hasil tersebut PT. Sentral Perkasa Jaya memiliki kekuatan utama yaitu pada jumlah armada yang banyak dengan nilai terbobot sebesar 0,4693 , sehingga masih dapat bersaing dengan pesaing-pesaing yang lain. Namun PT. Sentral Perkasa Jaya juga memiliki kelemahan utama yaitu kurangnya kegiatan promosi dengan nilai terbobot sebesar 0,1752. 
Matriks EFE diperoleh berdasarkan pengumpulan data melalui kuisioner.Pembobotan dan penilaian kuisioner berdasarkan hasil evaluasi faktor-faktor eksternal, berupa peluang dan ancaman yang berpengaruh terhadap pemasaran PT. Sentral Perkasa Jaya.Setelah diperoleh hasil nilai terbobot dan hasil peringkat dari faktor eksternal, berikutnya adalah menganalisis dari hasil tersebut. Berikut adalah hasil analisis menggunakan matriks EFE:

Tabel : 2. Tabel hasil Eksternal Factor Evaluation Matrix (EFE Matrix)

\begin{tabular}{lccc}
\hline Faktor Eksternal & $\begin{array}{c}\text { Nilai } \\
\text { Terbobot }\end{array}$ & $\begin{array}{c}\text { Nilai } \\
\text { Peringkat }\end{array}$ & $\begin{array}{c}\text { Total } \\
\text { Nilai }\end{array}$ \\
\hline $\begin{array}{l}\text { Tidak terikat } \\
\text { waktu }\end{array}$ & 0.133036 & 2.85 & 0.379152 \\
$\begin{array}{l}\text { Keamanan } \\
\text { terjaga }\end{array}$ & 0.132143 & 3 & 0.396429 \\
$\begin{array}{l}\text { Pangsa pasar } \\
\text { yang besar } \\
\text { Lokasi strategis }\end{array}$ & 0.119643 & 2.575 & 0.30808 \\
\hline \multicolumn{1}{l}{$\begin{array}{l}\text { Ancaman } \\
\text { Banyaknya } \\
\text { pesaing }\end{array}$} & 0.125 & 3.125 & 0.390625 \\
$\begin{array}{l}\text { Murahnya } \\
\text { harga pesaing }\end{array}$ & 0.123214 & 2.9 & 0.357321 \\
$\begin{array}{l}\text { Munculnya } \\
\text { kereta api }\end{array}$ & 0.120536 & 2.925 & 0.352567 \\
$\begin{array}{l}\text { Mahalnya BBM } \\
\text { Total }\end{array}$ & 0.120536 & 2.475 & 0.298326 \\
\hline & 0.129464 & 2.125 & 0.275112 \\
\hline
\end{tabular}

Berdasarkan tabel 4.6 hasil matriks IFE didapatkan total nilai terbobot sebesar 2,47. Berdasarkan hasil tersebut PT. Sentral Perkasa Jaya memiliki kekuatan utama yaitu pada keamanan barang-barang yang akan dikirim dengan nilai terbobot sebesar 0,3964. Tingginya tingkat keamanan yang selalu dijaga oleh perusahaan maka pelanggan menjadi lebih percaya untuk memakai jasa PT. Sentral Perkasa Jaya. Selain itu PT. Sentral Perkasa Jaya juga memiliki ancaman dari luar yaitu banyaknya pesaing-pesaing yang bekerja di bidang yang sama dengan nilai terbobot sebesar 0,3573 .

\section{Tahap Pencocokan}

Setelah memperoleh hasil analisis IFE dan EFE selanjutnya adalah membuat kurva SWOT untuk mengetahui situasi perusahaan saat ini. Berdasarkan matriks IFE dan matriks IFE telah didapatkan data total kekuatan (strength) perusahaan sebesar 1,47765, sedangkan data total kelemahan (weaknesses) perusahaan sebesar 0,993925. Sehingga dapat diperoleh nilai sumbu x yaitu selisih antara total kekuatan dan kelemahan perusahaan sebesar $+0,483725$. Selanjutnya untuk sumbu y adalah selisih antara ancaman (threats) di perusahaan dan peluang (opportunities) yang ada di perusahaan. Data total ancaman (threats) perusahaan sebesar 1,2833, sedangkan data total peluang (opportunities) perusahaan sebesar 1,474. Sehingga dapat diperoleh nilai sumbu x yaitu selisih antara total ancaman dan peluang perusahaan sebesar -0,19096. Berdasarkan matriks SWOT 
perusahaan ekspedisi PT. Sentral Perkasa Jaya pada tabel 4.7, maka dapat dilihat bahwa terdapat beberapa strategi alternatif yang sesuai dengan kondisi perusahaan, antara lain:

1. Integrasi horizontal

Strategi ini merupakan strategi untuk mengupayakan kendali lebih besar dari pada pesaing.Berdasarkan tabel 4.7 yang termasuk kedalam strategi ini adalah strategi SO-2 dan ST1.

2. Penetrasi pasar

Strategi ini merupakan strategi dengan meningkatkan pangsa pasar melalui upaya-upaya pemasaran yang lebih besar.Berdasarkan tabel 4.7 yang termasuk kedalam strategi ini adalah strategi WO-1.

3. Pengembangan produk

Strategi ini merupakan strategi pemasaran dengan cara memperbaiki atau memodifikasi barang yang ada diperusahaan saat ini. Berdasarkan tabel 4.7 yang termasuk kedalam strategi ini adalah strategi WO-2 dan WT-3.

4. Diversifikasi terkait

Strategi ini merupakan strategi pemasaran dengan cara menambah barang yang ada di perusahaan dan masih dibutuhkan untuk aktivitas perusahaan. Berdasarkan tabel 4.7 yang termasuk kedalam strategi ini adalah strategi SO-3 dan WO-3.

Matriks Internal-Eksternal (IE) merupakan alat manajemen strategis yang digunakan untuk menganalisis kondisi kerja dan posisi strategis bisnis.Matriks IE ini merupakan alat yang dapat digunakan untuk memposisikan perusahaan ke dalam matriks yang terdiri dari 9 sel. Matriks IE ini juga merupakan kelanjutan dari model matriks EFE dan IFE.Matriks IE juga bergantung pada dua kriteria dari matriks EFE dan IFE. Kriteria tersebut adalah skor dari matriks EFE akan diplot pada sumbu y sedangkan skor dari matriks IFE akan diplot pada sumbu x.

Berdasarkan data dari analisis lingkungan eksternal dan internal yang terjadi pada PT. Sentral Perkasa Jaya, diperoleh skor untuk matriks EFE sebesar 2,76 sedangkan skor untuk matriks IFE sebesar 2,47. Matriks IE dapat disusun setelah mendapatkan skor dari matriks EFE dan IFE.

Berdasarkan data yang terdapat pada gambar 4.1 dapat dilihat bahwa PT. Sentral Perkasa Jaya menempati kuadran V pada matriks IE (eksternal-internal). Hal ini membuktikan bahwa strategi yang sesuai untuk perusahaan yang menempati kuadran III, V, dan VII adalah hold and maintain strategy. Sehingga strategi yang sesuai untuk PT. Sentral Perkasa Jaya ini adalah:

1. Penetrasi pasar (Market Penetration)

Strategi ini adalah strategi yang bertujuan untuk meningkatkan pangsa pasar pada pasar yang sama dengan usaha pemasaran yang lebih intensif.

2. Pengembangan Produk (Product Development)

Strategi ini adalah strategi dimana perusahaan melakukan perbaikan produk yang sudah ada selama ini atau mengembangkan produk baru, sehingga dapat meningkatkan penjualan perusahaan.

\section{Tahap Keputusan}

Berdasarkan hasil perumusan strategi yang dibantu dengan dua alat bantu (matriks SWOT, dan Matriks IE) dihasilkan perbandingan alternatif strategi yang dapat digunakan oleh perusahaan. Setelah mengetahui hasil dari perbandingan alternatif strategi ini, maka dapat dilihat bahwa 
terdapat dua alternatif strategi yang paling banyak dirumuskan oleh kedua matriks tersebut.Kedua alternatif strategi tersebut adalah strategi penetrasi pasar dan strategi pengembangan produk.

Setelah mendapatkan dua strategi yang paling banyak dirumuskan, selanjutnya perlu ditentukan strategi mana yang paling sesuai dengan kondisi perusahaan saat ini. Sehingga masingmasing dari kedua strategi tersebut akan dinilai dengan menggunakan metode Quantitative Strategic Planning Matrix (QSPM). Metode ini digunakan untuk menentukan strategi mana yang paling baik untuk dipilih.QSPM ini juga merupakan alat yang direkomendasikan oleh para ahli strategi untuk melakukan evaluasi pilihan strategi alternatif secara objektif. QSPM ini juga memiliki penilaian yang sama dengan matriks IFE dan EFE, yaitu dengan menggunakan skala 1-4 untuk pemberian ratingnya, dimana nilai yang semakin tinggi menunjukan bahwa strategi tersebut sesuai dengan kondisi perusahaan.

Berdasarkan hasil penilaian QSPM pada tabel 4.9 dan 4.10 diketahui untuk strategi penetrasi pasar didapatkan skor pada faktor internal sebesar 2,702 sedangkan pada faktor eksternal sebesar 2,518 sehingga total skor yang diperoleh sebesar 5,22. Selanjutnya untuk strategi pengembangan produk didapatkan skor pada faktor internal sebesar 2,942 sedangkan pada faktor eksternal sebesar 2,527 sehingga total skor yang diperoleh sebesar 5,47 . Alternatif pengembangan produk ini mendapatkan skor yang lebih tinggi dibandingkan dengan alternatif penetrasi pasar.Sehingga dapat dikatakan bahwa strategi alternative yang paling sesuai untuk PT. Sentral Perkasa Jaya ini adalah strategi pengembangan produk.

Strategi pengembangan produk ini adalah strategi dimana perusahaan melakukan perbaikan produk yang sudah ada selama ini, atau mengembangkan produk baru, sehingga dapat meninggkatkan penjualan perusahaan. Berikut ini merupakan pemanfaatan strategi alternatif ini pada perusahaan ekspedisi PT. Sentral Perkasa Jaya:

1.Perusahaan dapat memanfaatkan peluang yang ada dari pertumbuhan infrastuktur dan memakai rute-rute yang baru yang belum pernah dilewati. Selain itu, pelayanan yang baik juga perlu diperhatikan sehingga dapat maksimal memberikan kepuasan konsumen.

2.Strategi pengembangan produk ini juga dapat diaplikasikan oleh perusahaan dengan cara bekerjasama dengan bank lokal. Sehingga metode pembayaran oleh pelanggan akan lebih mudah.

3.Perusahaan juga dapat membuat sistem online untuk meningkatkan kualitas perusahaan. Proses pemesanan dan pelayanan akan lebih mudah melalui sistem online ini, sehingga dapat meningkatkan pangsa pasar perusahaan.

4.Selain itu konsumen juga banyak yang mengantri untuk pengambilan barang, sehingga diperlukan gudang lagi untuk menampung barang-barang yang akan dikirim.

\section{KESIMPULAN}

Berdasarkan perumusan strategi yang telah dilakukan menggunakan dua alat bantu yaitu matriks SWOT dan matriks IE, maka strategi alternatif yang sesuai untuk kondisi perusahaan di PT. Sentral Perkasa Jaya adalah strategi penetrasi pasar (Market Penetration) dan strategi pengembangan produk(Product Development). Setelah mendapatkan dua alternatif strategi ini, selanjutnya akan dipilih strategi yang paling sesuai dengan kondisi perusahaan.

Proses pemilihan di antara dua alternatif strategi yang telah diperoleh, dengan menggunakan metode QSPM (Quantitative Strategic Planning Matrix). Berdasarkan hasil penilaian QSPM, menyatakan bahwa alternatif strategi yang terbaik adalah pengembangan produk (product development) dengan total skor 5,47 mengalahkan strategi alternatif penetrasi pasar (Market Penetration) yang sebesar 5,22. Strategi pengembangan produk ini adalah strategi dimana perusahaan melakukan perbaikan produk yang sudah ada selama ini, atau mengembangkan produk yang baru sehingga dapat meningkatkan penjualan. 
Berdasarkan penelitian yang sudah dilaksanakan pada PT. Sentral Energi Perkasa, terdapat beberapa saran untuk memaksimalkan penelitian yang sudah dilaksanakan yaitu perlu dilakukan analisis strategi pemasaran dengan menggunakan matriks SPACE dan matriks Boston Consulting Group danperlu dilakukan analisis strategi pemasaran dengan menggunakan metode Grand Strategy.

\section{DAFTAR PUSTAKA}

Assauri, S. 2008. Manajemen Produksi dan Operasi.Jakarta : Fakultas Ekonomi Universitas Indonesia.

Christoper, L. 2007. Manajemen Pemasaran Jasa. Jakarta : PT. Indeks Indonesia.

David, F. R. 2009. Manajemen Strategis. Edisi 12, diterjemahkan dari Bahasa Inggris oleh Ichsan. Jakarta: Salemba Empat.

Fauzi, A., Mas'ud, M. I. (2019). Proses Manufaktur pada Mesin Primer dan Sekunder CV. Karunia Menggunakan Metode Linier Programming. Journal Knowledge Industrial Engineering (JKIE), 6(2), 59-65. https://doi.org/10.35891/jkie.v6i2.2055

Firdaus, F. 2011. Perumusan Strategi Bersaing pada Industri Transportasi Trayek Jakarta-Bandung (Study Kasus PT. Primajasa Perdana Raya Utama).Skripsi.Fakultas Teknik Program Studi Teknik Industri Universitas Indonesia Jakarta.

Junaedi, D., Mas'ud, M. I. (2018). Penerapan Metode Forecasting dalam Perencanaan Produksi Bakpia dengan Menggunakan Software POM Guna Memenuhi Permintaan Konsumen. Journal Knowledge Industrial Engineering (JKIE), 5(3), 121-128. https://doi.org/10.35891/jkie.v5i3.2042

Kotler, P. 1998. Manajemen Pemasaran Prentice Hall Inc. Jilid 1 dan 2, Edisi 12 Jakarta: Erlangga.

Kotler, P. dan Armstrong, G. 2009.Prinsip-Prinsip Pemasaran.Jilid 1 dan 2, Edisi 12. Jakarta: Erlangga.

Kotler, P dan Keller, K. L. 2007. Manajemen Pemasaran. Jilid 1, Edisi 12 Jakarta: PT. Indexs.

Mas'ud, M. I. (2016). Pendekatan Rantai Markov Dalam Pemilihan Universitas Di Kabupaten Pasuruan. Journal Knowledge Industrial Engineering (JKIE), 4(1), 63-70

Porter, M. E. 2008. Strategi Bersaing (Competitive Strategy). Tanggerang: Karisma Publishing Group.

Rangkuti, F. 2009. Strategi Promosi yang Kreatif dan Analisis Kasus Integrated Marketing Communication. Jakarta: PT. Gramedia Pustaka Utama.

Saaty, T. 1993. Pengambilan Keputusan Bagi Para Pemimpin, Proses Hirarki Analitik Untuk Pengambilan Keputusan Dalam Situasi Yang Kompleks, diterjemahkan dari bahasa inggris oleh Peniwati. Jakarta: PT. Pustaka Binaman Pressindo. 